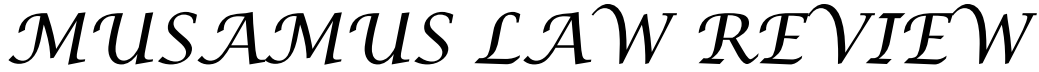

\author{
Volume 3 Issue 2, April 2021
}

Faculty of Law, Musamus University, Merauke, Papua, Indonesia

ISSN Online: 2621-959X, ISSN Print: 2621-9581

This work is licensed under a Creative Commons Attribution 4.0 International License.

\section{Application of Economic Analysis of Law Theory as a Basis for Courts' Judgements in Corruption Crime Cases: (Analyst's Decision of 45/Pid.Sus/TPK/2011/PN.BDG)}

\author{
Peter Jeremiah Setiawan', Madeleine Celandine Guinevere ${ }^{2}$, Fauzy Iskandar \\ Alamsyah $^{3}$, Mohammad Irvan ${ }^{4}$ \\ ${ }^{1}$ Faculty of Law, Universitas Surabaya, Surabaya-Indonesia, Peterjsetiawan@staff.ubaya.ac.id \\ 2 Faculty of Law, Universitas Airlangga, Surabaya-Indonesia, mcelandine@gmail.com \\ ${ }^{3}$ Faculty of Law, Universitas Airlangga, Surabaya-Indonesia, fauzy.iskandar@ymail.com \\ 4 Faculty of Law, Universitas Airlangga, Surabaya-Indonesia, irvan.mohammadbaswedan@gmail.com
}

\begin{abstract}
Mastery theory of law is one of the criteria for a good court. One of the law theories currently being developed is economic analysis of law theory. One of the decisions that the judge considered was using economic analysis of law theory in making a decision is a decision of 45/Pid.Sus/TPK/2011/PN.BDG. Therefore, this article will analyze further into the decision of 45/Pid.Sus/TPK/2011/PN.BDG. This research is legal research that uses statute approach, conceptual approach, and case approach. Based on the research, it showed that the features of economic analysis of law theory are: 1) Focused on the philosophy of justice utilitarianism which is the fundamental concept based on felicific calculus, 2) Using the basis of consideration: a) Economic theory as a foundation for legal analysis, b) Using analysis of cost-benefit to create a law and/or c) Consideration of opportunity cost which law will be formed, and 3) Output which is achieved is wealth maximization. Related to the Decision Number Register 45/Pid.Sus/TPK/2011/PN.BDG. in fact, arguable that judges make the decision based on economic analysis of law theory because related to ratio decedendi has fulfilled 3 (three) characteristic economic analysis of law theory.
\end{abstract}

\author{
ARTICLE INFO \\ Keywords: \\ Economic Analysis of Law; \\ Judges' considerations; \\ Decision. \\ How to cite: \\ Setiawan, P. J., Guinevere, \\ M. C., Alamsyah, F. I., \\ Irvan, M. (2021). \\ Application of Economic \\ Analysis of Law Theory as a \\ Basis for Courts' Judgments \\ in Corruption Crime Cases: \\ (Analyst's Decision of 45 / \\ Pid.Sus / TPK/2011 / \\ PN.BDG). Musamus Law \\ Review, 3(2), 84-96
}

Copyright (C) 2018 MuLaRev. All rights reserved.

\section{INTRODUCTION}

Geef me goede rechter, goede rechter commissarisen, goede officieren van justitien, goede politie ambtenaren, en ik zal met een slecht wetboeken van strafprocessrecht het geode 
beruken. ${ }^{1}$ A legal adage which if translates means:2 "Give me a decent judge, prosecutor, and policeman, and I will turn a poor criminal procedure code into good." If interpreted as a contra rio, it is understandable that if there are poor judges, prosecutors, and cops, decent criminal procedural law will deteriorate. ${ }^{3}$ This was clear from the legal adage that no matter how full the current legal substance is the rule would be difficult to enforce without any of the help of better police officers.

Based on the legal adage above, it can be seen that one of the law enforcers is a judge. The position of the judge as one of the law enforces was also shared by Henry Arianto who stated:4 "The role of judges is important. He is the laws and justice's enforcer, as well as state officials who do noble task in realizing a rule of law, providing legal certainly, and benefiting the community through legal decisions in court." According to Fence M. Wantu, one of the things must be practiced to be "great" judge is the science of law. ${ }^{5}$ The following are opinions from Fence M. Wantu: ${ }^{6}$ "Ideally, judges must master in development of legal science. Mastery of the science of law is something which cannot be ignored by judges in carrying out their daily duties."

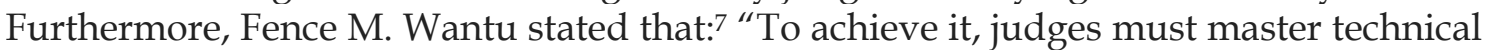
legal theories, such as legal interpretation and construction, which in this principle provide room for judges to find a case being examined and motivation to judges do not be fixated on the sound of the articles' clauses. The rule of law is an inert article." Based on this opinion, it can be seen that to be a great judge, it is one of thing which should be mastered by legal theory (rechtstheorie). ${ }^{8}$

Talking about legal theory has been around for a long time, in fact, legal principle has been begun to develop since the 1800s. ${ }^{9}$ There are several legal theories are known today, for example, the social theory of Jean Jacques Rousseau10, pure legal theory (théorie pure du droit) from Hans Kelsen11, legal theory as a reflection of the people's soul (volkgeist) ${ }^{12}$ from Friedrich Carl von Savigny, etc. One legal theory is arguably new in comparison to other legal theories, but it has gained widespread recognition and application is the economic analysis of law theory popularized by Richard A. Posner. ${ }^{13}$

${ }^{1}$ Yohanes Suhardin. (2009). "Fenomena Mengabaikan Keadilan Dalam Penegakan Hukum". Mimbar Hukum, 21(2): 350-351.

2 Tri Andrisman. (2008). Sistem Peradilan Indonesia; (Sebelum dan Sesudah Merdeka). Bandar Lampung: Universitas Lampung, p. 63.

${ }^{3}$ Satjipto Rahardjo. (2007). Mendudukkan Undang-Undang Dasar, Suatu Pembahasan dari Optik Ilmu Hukum Umum. Semarang: Badan Penerbit Universitas Diponegoro, p. 88-89.

${ }^{4}$ Henry Arianto. (2012). "Peranan Hakim Dalam Upaya Penegakan Hukum Di Indonesia". Lex Jurnalica, 9(3): 155-156.

${ }^{5}$ Fence M. Wantu. (2013). "Kendala Hakim Dalam Menciptakan Kepastian Hukum, Keadilan, Dan Kemanfaatan Di Peradilan Perdata". Mimbar Hukum, 25(2): 211-212.

${ }^{6}$ Ibid.

${ }^{7}$ Ibid.

${ }^{8}$ Shevierra Danmadiyah, Xavier Nugraha, Sayyidatul Insiyah . (2019). "A Party's Recall Right in the Concept of Democratic Country". Syariah: Jurnal Hukum dan Pemikiran, 19(2): 151-152

${ }^{9}$ Danrivanto Budhijanto. (2014). Teori Hukum Konvergensi. Bandung: Refika Aditama, p. 10-11.

${ }^{10}$ M. Zulfa Aulia. (2020). "Friedrich Carl von Savigny tentang Hukum: Hukum sebagai Manifestasi Jiwa Bangsa". Undang: Jurnal Hukum, 3(1): 202-203.

${ }^{11}$ FX. Adji Samekto. (2019). "Menelusuri Akar Pemikiran Hans Kelsen Tentang Stufenbeautheorie Dalam Pendekatan Normatiffilosofis". Jurnal Hukum Progresif, 7(1): 1-2.

${ }^{12}$ Idrus Ruslan. (2013). "Pemikiran "Kontrak Sosial" Jean Jacques Rousseau Dan Masa Depan Umat Beragama". Undang: Jurnal Hukum, 3(1): 19-20.

${ }^{13}$ Richard A. Posner. (2014). Economic Analysis of Law. Ninth edition. New York: Wolters Kluwer Law $\&$ Business, p. 1-2 
Economic analysis of law theory which popularized by Richard A. quite rapidly popularity, because it is considered that this theory is a breakthrough in legal theory that changes the traditional views of legal experts who previously only considered law related to "right" and "wrong", however, it includes the elements of "risks" and "benefit" or it known as R\&B. ${ }^{4}$ The aim of R\&B elements in legal theory is carried out by Posner to create and encourage the maximum efficiency of the created legal product. Posner also refers to express that as "wealth maximization." 15 Thus, it can be said that in essence, through this economic analysis of low theory, the aim of law to be produced is to achieve an effective and efficient law.

The existence of economic analysis of law theory which is predicted as a revolutionary legal theory is of course compulsory for the control of judges who are required to master legal theory. In Indonesia, it appears that judges have begun to use economic analysis of law theory as a basis for giving decisions. One of the examples of judge's decision using economic analysis of law theory as a basis for making decisions can be seen in a corruption case with register number 45/Pid.Sus/TPK/2011/PN.BDG.

The case stems from the action of Yoyo Iryadi bin Djaya Dinata who is the village head in Linggar Village, Rancaekek District, Bandung Regency who is accused of corruption. The action allegedly carried out by Yoyo as the Village head was transfer of funds and the remaining funds could not be accounted for. This was revealed based on the results of the examination by Bandung Regency Inspectorate Number: 700/713C/IRBAN III December 2, 2010, about the Realized Work Examination Report, supplemented by witness testimony, evidence, and even the defendant's testimony. Meanwhile, the amount of funds that the defendant could not account for was Rp500.000,00, - (five hundred thousand rupiah).

The judge claimed that the defendant's acts were proven but this act was not a criminal act, so the judge gave the decision that the defendant was acquitted of all legal charges (Onslag Van Rechts Alle Voervolging). One of the judges' considerations in making the decision was: "Whereas by taking into account the principle of the costbenefit ratio, in common sense it is not worth the cost incurred by the state to examine and hear state losses is $\mathrm{Rp} 500.000$, -."

Related to the background, this article will analyze Decision Number 45/Pid.Sus/TPK/2011/PN.BDG and colleration with economic analysis of law theory. To conduct research on Decision Number 45/Pid.Sus/TPK/2011/PN.BDG and colleration with economic analysis of law theory, the problem formulations in this article are: 1) What are the characteristic of economic analysis of law theory and 2) What is the ratio decedendi of Decision Number 45/Pid.Sus/TPK/2011/PN.BDG. The objective of this article are: 1) to analyze and find the characteristics of economic analysis of law theory dan 2) to analyze and find the ratio decedendi of Decision Number 45/Pid.Sus/TPK/2011/PN.BDG.

There are several articles that are similar to this one, so to ensure the novelty of this article, the researcher will describe the differences between these articles and the novelty of this article. Some of the articles that are similar to this one are:

1. Sudwijayanti's article with the title: "Economic Analysis of Law Against Criminalization of Insider Trading in the Merger Process as a Corporate Crime"

\footnotetext{
14 Romli Atmasasmita dan Kodrat Wibowo. (2016). Analisis Ekonomi Mikro tentang Hukum Pidana Indonesia. Cetakan kesatu. Jakarta: Prenadamedia Group, p.5.

${ }^{15}$ Richard A. Posner. (2013). "Wealth Maximization Revisited". Notre Dame Journal of Law, Ethcis, and Public Policy, 2(1): 85-86.
} 
was published DIH: Journal of Legal Studies Volume 13 Number 25, 2017. Article is same with before to discuss related to economic analysis of law theory, but the differences is this article from Sudwijayanti that it correlates with the conviction of insider trading in the merger process as corporate crime $^{16}$, wherease in this article it correlates with criminal acts of corruption, especially in Decision Number 45/Pid.Sus/TPK/2011/PN.BDG.

2. Isti Sulistyorini and Siti Zulaekhahs' article with the title: "Economic Analysis of Law on Changes in the Policy of a Contract of Work into a Special Mining Business Permit (IUPK): A case Study of PT. Freeport Indonesia" which was published in journal Pena Justisia: Media Communication and Legal Studies Volume 17, Number 2, 2017. This article by Isti Sulistyorini and Siti Zulaekhah discuss about economic analysis of law theory, but the differences in this article by Isti Sulistyorini and Siti Zulaekhah collates with the change in contract of work policy to a special mining license which is especially correlated with cause study of PT. Freeport Indonesia ${ }^{17}$, while this article correlates it with criminal acts of corruption, especially in Decision Number 45/Pid.Sus/TPK/2011/PN.BDG.

\section{METHOD}

The research is legal research. According to Jonaedi Effendi and Johhny Ibrahim, legal research is a research which has a legal object, law as a science or dogmatic rules, as well as law related to people's behavior and life. ${ }^{18}$ This research is a legal research to analyze the rules and laws relating to the application of the theory economic analysis of law as a basis for judges' consideration in Decision of corruption.

To obtain answers to the legal issues faced, this research uses several approaches are statute approach, conceptual approach, dan case study. The first approach is the statutory approach. The statutory approach is used to examine various laws and regulations related to legal issues at hand, including Law Number 31 in 1999 about Eradication of Corruption Crimes as Amended by Law of the republic of Indonesia Number 20 in 2001, law Number 48 in 2009 about Judicial Power, and so on. The next approach is the conceptual approach which in according to Peter Mahmud, the conceptual approach is used to study views and doctrines in legal science to find legal definitions, legal concepts and legal principles which relevant to the issues at hand. ${ }^{19}$ In this legal research, the legal concept which use is economic analysis of law. The final approach is a case study which in fact is often considered the same as the case approach even though there are differences, such as the case approach analyzes several decisions with permanent legal force (inkracht van gewijsde) 20 , while case study just analyzing a case, where in this article is Decision Number 45/Pid.Sus/TPK/2011/PN.BDG.

16 Sudwijayanti. (2017). "Economic Analysis Of Law Terhadap Pemidanaan Insider Trading Dalam Proses Merger Sebagai Kejahatan Korporasi”. DiH Jurnal Ilmu Hukum, 13(25): 131-145.

${ }^{17}$ Isti Sulistyorini dan Siti Zulaekhah. (2017). "Economic Analysis of Law pada Perubahan Kebijakan Kontrak Karya Menjadi Ijin Usaha Pertambangan Khusus (IUPK): Studi Kasus PT. Freeport Indonesia". Pena Justisia: Media Komunikasi dan Kajian Hukum, 17(2): 71-79.

18 Jonaedi Effendi dan Johhny Ibrahim. (2020). Metode Penelitian Hukum Normatif dan Empiris. Cetakan Ketiga. Jakarta: Kencana, p.16.

${ }^{19}$ Peter Mahmud Marzuki. (2010). Penelitian Hukum, Cetakan ke-6. Jakarta: Kencana Prenada Media Group, p.93.

${ }^{20}$ Ibid. 


\section{RESULTS AND DISCUSSION}

\subsection{The Characteristic Economic Analysis of Law Theory}

Defining a concept is not the only way to describe it, particularly if it comes to a complicated legal concept. ${ }^{21}$ This is in accordance with the sarcasm of Immanuel Kant, that:22 "Noch suchen die Juristen eine Definition zu ihrem Begriff von Recht (Translated based on means: legal experts are still looking for a definition of their legal concept)."it is recognized that looking for a description of the concept of law does not cause one to lose sight if the meaning of understanding of the law. Regarding the definition of economic analysis of law theory, no one has provided a precise definition, but if you look at the opinion of John Posner, it can be understood that in essence economic analysis of law theory is a legal theory regarding economic analysis of law or analysis of law or economics about law. ${ }^{23}$

To understand the essence of economic analysis of law theory which is a legal theory, it is necessary to first understand the philosophy that supports the legal theory thinking. It is intended that the rationale for this legal theory is obtained so that a holistic understanding can be formed regarding this economic analysis of law theory. The importance of understanding the legal philosophy that underlies a legal theory is also coherent with the opinion of Shidarta, who stated that 24 "Legal philosophy provides a philosophical basis and after the birth of legal theory as an independent discipline, it is also a philosophical basis for legal theory..." As a basic giver, legal philosophy becomes a reference for the teachings of values and teachings of science for legal theory 25

Table 1. Philosophy in Law School

\begin{tabular}{|c|c|c|c|}
\hline Number & $\begin{array}{c}\text { Name of } \\
\text { Philosophy in Law } \\
\text { School } \\
\end{array}$ & $\begin{array}{l}\text { Thesis of } \\
\text { Philosophy in } \\
\text { Law School }\end{array}$ & Main Idea of Legal Philosophy \\
\hline 1. & Natural Law & $\begin{array}{l}\text { Thesis of Morality } \\
\text { and Normativity }\end{array}$ & $\begin{array}{l}\text { Natural law unites law and morals, but it } \\
\text { separates law and facts }\end{array}$ \\
\hline 2. & Legal Realism & $\begin{array}{l}\text { Thesis on } \\
\text { Separation of Law } \\
\text { and Morals and } \\
\text { the Unity of Law } \\
\text { and Fact }\end{array}$ & $\begin{array}{l}\text { Law separates law and morals and unites } \\
\text { law and facts }\end{array}$ \\
\hline 3. & Pure Theory of Law & $\begin{array}{l}\text { Separation of Law } \\
\text { and Moral Thesis } \\
\text { and Normativity }\end{array}$ & $\begin{array}{l}\text { Synthesis of the thesis of natural law and } \\
\text { empirical positivism. The normative } \\
\text { thesis of natural law and the thesis of the } \\
\text { separation between law and morals from } \\
\text { empirical positivism are taken and made } \\
\text { into the thesis of pure legal theory. }\end{array}$ \\
\hline
\end{tabular}

${ }^{21}$ Philipus M. Hadjon et.al. (2005). Pengantar Hukum Administrasi, Cetakan ke-9. Yogyakarta: Gadjah Mada University Press, p.21.

${ }^{22}$ Lukas Heckendorn Urscheler dan Seán Patrick Donlan. (2014). Concepts of Law: Comparative, Jurisprudential, and Social Science Perspectives. Farnham: Ashgate Publishing, Ltd, p.21.

${ }^{23}$ Sophie Harnay dan Alain Marciano. (2009). "Posner, Economics And The Law: From "Law And Economics" To An Economic Analysis Of Law". Journal of the History of Economic Thought, 31(2): 216-217.

24 Shidarta. (2013). Hukum Penalaran dan Penalaran HukumAkar Filosofis. Yogyakarta: Genta Publishing, p.282.

25 Mahrus Ali. (2017). "Pemetaan Tesis dalam Aliran-Aliran Filsafat Hukum dan Konsekuensi Metodologisnya". Jurnal Hukum IUS QUIA IUSTUM, 2(24): 216-229. 
4. School of History

5. American
Sociological
Jurisprudence;

6. Utilitarianisme;
Thesis on Morality and the Unity of Law and Fact

Thesis on the Separation of Law and Morals and the Unity of Law and Facts
Thesis on the Separation of Law and Morals and the Unity of Law and Facts
Moral values according to the historical school are limited to the soul of each nation (volksgeist) so that their scope is particular

A synthesis of legal positivism and historical schools, American Sociological Jurisprudence is different from legal positivism and historical schools. If legal positivism makes positive norms in the statutory system the main thing, American Sociological Jurisprudence places it as just a way to solve a concrete case. This flow also limits the concept of law as judge-made law.

The concept of law according to utilitarianism is the same as the concept of law according to pure legal theory, namely positive norms in the statutory system. The thing that distinguishes the dimensions of epistemology and axiology in which utilitarianism uses a deductive and non-doctrinal methodology is linearly inductive. Positive norms in the statutory system must be tested in the real world. Therefore, the value of legal certainty is followed by the value of the benefit.

Source: Mahrus Ali, 2017

Based on the various philosophical school that exists, it can be understood that the philosophy underlying the birth of the economic analysis of law is the Utilitarianisme which popularized by Jeremy Bentham. This utilitarianisme developed by Jeremy Bentham is based on felicific calculus, which is the calculation of great happiness over large numbers. ${ }^{26}$ This is what underlines Jeremy Bentham's opinion, which is often known as the greatest happiness number or known as the principle of expediency. ${ }^{27}$

After recognizing that the basis of thinking from economic analysis of law theory is the flow of utilitarianisme which the main principle is based on felicific calculus, it is logical of economic analysis of law theory the things used as a basis in forming law are: 28

1. Economic theory as a basis for analyzing law

2. Using cost-benefit analysis in shaping law

3. Considering the opportunity cost of the established law

The expected results (output) from the use of these 3 (three) things in forming laws that reflect the economic analysis of law theory is Wealth Maximization. As an embodiment of economic analysis of law theory, which in fact the focus is the application of the

${ }^{26}$ Muyassarotussolichah. (2007). "Aliran Teori Hukum Kritis: Analisis Ekonomi terhadap Hukum (The Economic Analysis of Law) Dalam Jurisprudence: Hilaire McCoubrey and Nigel D. White)". SOSIORELIGIA, 7(1): 215-215.

27 Ian McLeod. (2005). Legal Theory (Palgrave Law Masters). New York: Palgrave MacMillan Ltd, p.164.

${ }^{28}$ Danrivanto Budhijanto Op.cit., p.21. 
principles of efficiency and benefit, the concretization of efficiency and benefit is a condition where the resources are allocated so that the value is maximum or also known as wealth maximization. ${ }^{29}$

From a series of explanations, it can be understood that the characteristics of economic analysis of law are:

1. Based on the theory of utilitarian justice, which in fact the main principle based on felicific calculus;

2. Using the basic considerations

- Economic theory as the basis for analyzing law;

- Using cost-benefit analysis in shaping laws; and/or

- Considering the opportunity cost of the law established

3. The output to be achieved is a wealth maximation

\subsection{Ratio decedendi Judges from Decision Number 45/Pid.Sus/TPK/2011/PN.BDG}

In Article 5 paragraph (1) in Law Number 48 in 2009 about Judicial Power (Law 48/2009), it is stipulated that: "Constitutional judges and judges are obliged to explore, follow and understand the legal values and the sense of justice that Public." Grammatically, it can be seen that there is the phare "obliged to explore, follow, and understand." From the operator the selected norm is mandatory, so this means that the judge must explore, follow, and understand the legal values and the sense of justice that live in society. As for the concretization of the 3 (three) things that have been done by the judge, it can be seen from the judge's consideration (ratio decedendi) as outlined in his decision. ${ }^{30}$ This is coherent with the opinion of A. W. B. Simpson who states that: 31 "the ratio decedendi can be defined as the material facts of the case plus the decision theron." The obligation of judges to explore, follow, and understand and to ensure that what is concretized is based on the judge's consideration which then becomes one of the ratios legis of the existence of Article 53 paragraph (1) UU 48/2009 which reads: "The decision and decision as referred to in paragraph (1) must contain judges' legal considerations based on proper and correct reasons and legal grounds." Thus, every decision should have a ratio decedendi, because it is from there that the basis for the judge's consideration can be understood to issue a decision.

In this article, the decision that will be analyzed for ratio decedendi is Decision Number 45/Pid.Sus/TPK/2011/PN.BDG, so that it can be understood the basis used by the judge in making a decision. However, before discussing the ratio decedendi $\mathrm{f}$ the judge in passing Decision Number 45/Pid.Sus/TPK/2011/PN.BDG, the position and decision of the judge from Case Register Number 45/Pid.Sus/TPK/2011/PN.BDG. This is actually in accordance with the adage of the classical law, are32 "id perfectum est quod ex omnimbus suis partibus constant" which if freely translated means: "something cannot be said to be perfect unless it is said to be complete." In connection with this

\footnotetext{
${ }^{29}$ Muhammad Rustamaji. (2013). "Menakar Pengawasan Pemberian Bantuan Hukum Dalam Pandangan Richard A Posner". Jurnal Rechtsvinding: Media Pembangunan Hukum Nasional, 2(1): 99-102.

${ }^{30}$ Nina Amelia Novita Sari et.al. (2019). "Implikasi Penafsiran Hak Menguasai Negara Oleh Mahkamah Konstitusi Terhadap Politik Hukum Agraria Pada Pulau-Pulau Kecil Di Indonesia”. Law Review , 19(2): 171-172.

${ }^{31}$ A. W. B. Simpson. (1959). "The Ratio Decidendi of a Case". The Modern Law Review, 22(5): 118-119.

32 Jihan Anjania Aldi, Elma Putri Tanbun, Xavier Nugraha. (2019). "The Ratio Decidendi of a Case". JURNAL HUKUM DE'RECHTSSTAAT, 5(2): 137-139.
} 
article, with the elaboration of the case position and the judge's decision from Decision Number45/Pid.Sus/TPK/2011/PN.BDG, before analyzing the ratio decedendi in Case Register Number 45/Pid.Sus/TPK/2011/PN.BDG, then it will make the analysis of the ratio decedendi in Case Register Number 45/Pid.Sus/TPK/2011/PN.BDG to be perfect.

The position case of Case Number Register 45/Pid.Sus/TPK/2011/PN.BDG stems from the action of Yoyo Iryadi bin Djaya Dinata who served as the village head in Linggar Village, Rancaekek District, Bandung Regency who was suspected of having committed acts of corruption. The action allegedly carried out by Yoyo as the village head was the transfer of funds and the remaining funds that could not be accounted for. This was revealed based on the results of the inspection from the Inspectorate of Bandung Regency Number: 700/713C/IRBAN III on December 2, 2010 about the Report on the Results of the Examination of Realized Work. The details of the funds are as follows:

1. Fund for repairing the Al-Ikhlas mosque at Rt. 02 Rw.08, Bangkuang Village, Linggar Village, Rancaekek District, amounting to Rp. 30,000,000.00 (thirty million rupiah), in fact it is realized for:

- The cost of the Al-Hijrah Rancapait mosque is Rp10.000.000,00;

- The Cihaur road Raston fee is Rp 12.850.000,00;

- The Raston fee for Jalan Bojongkalong is Rp 5.628.000,00

- Buy Sand and Stone for Depok roads is Rp 1.522.000,00

2. Wajardiknas fund amounting to $\mathrm{Rp} 5.500 .000,00$ (five million five hundred thousand rupiahs) for school equipment packages for students who cannot afford a total of 55 students each Rp 100.000,00 the defendant realized, among others:

- Assistance for Paud Aurora in the amount is Rp 4.500.000,00

- Assistance for Paud Miftahul Huda in the amount is Rp 1.000.000,00

3. The environmental road hardening fund Rw.08 of Rp. 2,000,000.00 (two million rupiahs) is diverted to the construction of culverts in the area of Rt.02 Rw.01;

4. Funds for Village Apparatus Empowerment for Human Resources Improvement Training for Phase II LPMD amounting to Rp. 1,500,000.00 are realized in the amount of $\mathrm{Rp} .1,000,000.00$ so that there is a remaining fund of Rp. 500,000.00, - was used for the purchase of food and drink as well as for the cost of the pedicab for transporting food and beverages for human resource development activities for LPMD and when the inspection was carried out by the Inspectorate, the Defendant could not yet account for

As for the remaining funds, the defendant was charged with alternative charges are First, Article 3 jo Article 18 paragraph (1) letter a and letter b of Law Number 31 in 1999 about Eradication of Corruption Crimes as amended by Law Number 202001 about Amendments to Law Number 31 in 1999 about Eradication of Corruption jo with Article 65 of the Criminal Code (KUHP) or Second, Article 8 of Law Number 31 in 1999 about Eradication of Corruption Crimes as amended by Law Number 20 in 2001 about Amendments to Law Number 31 in 1999 about Eradication of Corruption jo with Article 65 paragraph (1) of the Criminal Code or Third, Article 9 of Law Number 31 in 1999 about Eradication of Corruption as amended with Law 
Number 20 in 2001 about Amendments to Law Number 31 in 1999 about Eradication of Corruption jo Article 65 paragraph (1) of the Criminal Code.

In this case, the judge ruled:

1. Declare the acts accused as in the first indictment (criminal threats in accordance with Article 3 jo with Article 18 paragraph (1) letters a and b of Law Number 31 in 1999 about Eradication of Corruption as amended by Law Number 20 in 2001 about Amendments to Law Number 31 in 1999 about Eradication of Corruption jo with Article 65 paragraph (1) KUHP) to Defendant Yoyo Iryadi Bin Djaya Dinata was proven but this act was not a criminal act;

2. To declare that the Defendant, Yoyo Iryadi Bin Djaya Dinata released from all legal charges (Onslag Van Rechts Alle Voervolging) in this case;

3. Recover the rights of the Defendant Yoyo Iryadi Bin Djaya Dinata in terms of ability, position and dignity.

The ratio decedendi used by the judge, in this case, is basically:

1. the element of committing several actions, each of which must be viewed as separate actions that have been fulfilled;

2. Even though the actions of the Defendant, Yoyo Iryadi Bin Djayadinata as above have met the formal formulation (procedural justice), the judge is of the view that the character of criminal law justice prioritizes (substantive justice). The judge here considers whether the actions of the defendant who has violated the formal law have also violated the material law. To find that answer, the judge referred to the legal doctrine regarding the teaching of the nature of against the material law in its negative function. The nature of against negative material law is based on unwritten law is the view of the community that an act is not disgraceful or not against the law materially, even though it has fulfilled the formulation of the offense, the perpetrator is released from all legal claims. ${ }^{33}$ The use of this doctrine is also complemented by judges on a written legal basis in the form of jurisprudence which has been adhered to as a standard reference and is consistently applied (stare decicis), is as in the decision of the Supreme Court No. 42 K/KR/1966, in January 8, 1966, No. 71/K/1970, in May 27, 1972; and No. 81/K/KR/1973, in March 30, 1977, which in essence was that even though the defendant's act was against the formal law but not against the law materially, the defendant had to be released from all charges because:

- The state is not harmed;

- Public interest served;

- The defendant did not get any benefits.

3. Regarding funds amounting to Rp. 500,000, which at the time of inspection by the Inspectorate could not be accounted for by the defendant and in the trial, it was proven that it was used for the purchase of food and drink as well as for pedicab costs for transporting food and drinks for human resource development activities for LPMD, as well as the transfer of funds. which was not in

${ }^{33}$ Erdianto Effendi, Hukum Pidana Indonesia, Suatu Pengantar, Refika Aditama, Bandung, 2011, hlm. 118 
accordance with its designation but all of this was done by the defendant as a result of deliberation and used for the construction of public facilities (repair of roads, mosques, and PAUD buildings), and it was also proven at court that the defendant had paid out personal money of Rp. 25,000,000. to carry out the normalization of Cikijing River, so that in essence the state was not harmed, the public interest was served, and the defendant did not benefit at all;

4. The act of the defendant in transferring funds as above, in addition to having fulfilled the procedure (is deliberation which was strengthened by the Decree of the Head of Linggar Village, Rancaekek District, Bandung Regency No. 141.1 / Kep-02-2004 / 2010 on June 28, 2010).

5. Whereas the transfer decision by the defendant Yoyo was a form of discretion about the will/demands of the Linggar Village community regarding damage to public facilities and situations that were difficult to anticipate (the Cikijing River flood) so that the diversion could be called a rational and beneficial decision which had to be carried out immediately at that time. Even if there is an error in the defendant's actions, it tends to be administrative in nature.

6. Whereas by observing the principle of the cost-benefit ratio, in common sense it is not comparable to the costs incurred by the state to examine and hear state losses of Rp. 500,000. The examination of a case with a small amount of loss is not in accordance with: the parameters of restorative justice that are in accordance with the ideal value or ideals of justice (ius constituendum) of our nation as stated in the Corruption Eradication Bill is according to article 51 which is essentially a corruption case. with state losses of up to Rp. 25,000,000, there is no need to go to court, the use of the principle of punishment as the ultimate remidium, so law enforcers need to apply criminal sanctions frugally and carefully.

From the legal facts, decisions, and ratio decedendi in the case decision Register Number 45 / Pid.Sus / TPK / 2011 / PN.BDG, it can be seen that the judge in making the decision adopted ecomic analysis of law theory. This can be seen from the characteristics of the economic analysis of law which are reflected in the ratio decedendi of the decision number Register Number 45 / Pid.Sus / TPK / 2011 / PN.BDG. Here is the description:

1. Based on the theory of utilitarian justice, which in fact the main principle is based on felicific calculus

In this case, it can be seen that the judge of the theory of utilitarian justice, whose main principle is based on felicific calculus, applies the felicific calculus principle from the consideration of the judge who considers that: "Regarding funds amounting to Rp. 500,000, - which at the time of the inspection the Inspectorate could not be accounted for by the defendant. and in court it was proven that it was used for the purchase of food and drink as well as for the cost of the rickshaw to transport food and drinks for human resource development activities for LPMD, as well as the transfer of funds that were not in accordance with their allocation but all of this was carried out by the defendant as a result of deliberation and used for the construction of public facilities. (repair of roads, mosques, and PAUD buildings), and it was also proven at the trial that the defendant had spent Rp. 25,000,000 in private money to carry out the 
normalization of Cikijing River so that in essence the state was not harmed, the public interest was served, and the defendant did not benefit at all. " From these considerations, it can be seen that the judges considered that in relation to the money that could not be accounted for, the community had agreed to use it for the purchase of food and drink as well as for pedicab costs for transporting food and beverages for HR improvement activities for LPMD, in addition to the transfer of funds that were not according to its designation but all of this was carried out by the defendant based on the results of deliberation and used for the construction of public facilities (repair of roads, mosques and PAUD buildings, so this means that all parties, in the sense of the village community, have agreed and received the majority of benefits, so the judges who understand this can be said to have used the basis of felicific calculus in making decisions.

2. Using the basic considerations:

- Economic theory as the basis for analyzing law;

- Using cost-benefit analysis in shaping laws; and/or/

- Considering the opportunity cost of the law established.

In one of his considerations, it was stated that: "Whereas by taking into account the principle of the cost-benefit ratio, it is common sense that it is not comparable to the costs incurred by the state to examine and hear state losses of Rp. 500,000. The examination of a case with a small amount of loss is not in accordance with: the parameters of restorative justice in accordance with the ideal value or the ideal of justice (ius constituendum) of our nation. From these considerations, it can be seen that expressis verbis the judge mentions the cost-benefit ratio which incidentally means the judge uses one of the basic considerations in the economic analysis of law theory in making this decision.

3. The output to be achieved is a wealth maximation

From the results to be achieved from this decision which incidentally is that the defendant is acquitted of all legal charges (Onslag Van Rechts Alle Voervolging), because the money is used based on a joint agreement for the benefit of the villagers and de facto indeed for the villagers, and if convicted is not In accordance with the principle of the cost-benefit ratio which is not worth the cost incurred by the state to examine and hear state losses, it can be seen that the results achieved want to "maximize welfare", because all parties are considered "welfare", including welfare for villagers (money used for villagers themselves), the state (it is not worth the costs incurred by the state to further examine and try this case), and the defendant himself (money that must be spent to pay lawyers and so on when the defendant is convicted).

\section{CONCLUSION}

The characteristics of economic analysis of law theory are: 1) Based on the theory of utilitarian justice, which in fact the main principle is based on felicific calculus, 2) Using basic considerations: a) Economic theory as a basis for analyzing law, b) Using cost-benefit analysis in form a law and/or c) Consider the opportunity cost of the law formed, and 3) The output to be achieved is wealth maximization. Related to the 
Decision Register Number 45 / Pid.Sus / TPK / 2011 / PN.BDG. In fact, judges in making decisions are arguably based on economic analysis of law theory, because the decedendi ratio has met 3 (three) characteristics of economic analysis of law theory.

To guarantee legal certainty, so that this economic analysis of law theory can be used by judges as a basis for ruling on corruption, the criteria for this economic analysis of law theory can be stated in a Supreme Court Circular (SEMA). In the context of decisions whose ratio decedendi use economic analysis of law theory so that they can be used as sources by other judges, they can qualify as case law or landmark decisions.

\section{REFERENCES}

Aldi, Jihan Anjania, Elma Putri Tanbun, Xavier Nugraha. (2019). "The Ratio Decidendi of a Case". JURNAL HUKUM DE'RECHTSSTAAT, 5(2), 137-147.

Ali, Mahrus. (2017). "Pemetaan Tesis dalam Aliran-Aliran Filsafat Hukum dan Konsekuensi Metodologisnya". Jurnal Hukum IUS QUIA IUSTUM,, 2(24), 213-231. doi: 10.20885/iustum.vol24.iss2.art3

Andrisman, Tri. (2008). Sistem Peradilan Indonesia; (Sebelum dan Sesudah Merdeka). Bandar Lampung: Universitas Lampung.

Arianto, Henry. (2012). "Peranan Hakim Dalam Upaya Penegakan Hukum Di Indonesia". Lex Jurnalica, 9(3), 151-163.

Atmasasmita, Romli dan Kodrat Wibowo. (2016). Analisis Ekonomi Mikro tentang Hukum Pidana Indonesia. Cetakan kesatu. Jakarta: Prenadamedia Group.

Aulia, M. Zulfa. (2020). “Friedrich Carl von Savigny tentang Hukum: Hukum sebagai Manifestasi Jiwa Bangsa". Undang: Jurnal Hukum, 3(1), 201-236. doi: https://doi.org/10.22437/ujh.3.1.201-236.

Budhijanto, Danrivanto. (2014). Teori Hukum Konvergensi. Bandung: Refika Aditama.

Danmadiyah, Shevierra, Xavier Nugraha, Sayyidatul Insiyah . (2019). “A Party's Recall Right in the Concept of Democratic Country". Syariah: Jurnal Hukum dan Pemikiran, 19(2), 151-158. doi: http://dx.doi.org/10.18592/sjhp.v19i2.3184

Effendi, Erdianto, Hukum Pidana Indonesia, Suatu Pengantar, Refika Aditama, Bandung, 2011.

Effendi, Jonaedi dan Johhny Ibrahim. (2020). Metode Penelitian Hukum Normatif dan Empiris. Cetakan Ketiga. Jakarta: Kencana.

Hadjon, Philipus M. et.al. (2005). Pengantar Hukum Administrasi, Cetakan ke-9. Yogyakarta: Gadjah Mada University Press.

Harnay, Sophie dan Alain Marciano. (2009). "Posner, Economics And The Law: From "Law And Economics" To An Economic Analysis Of Law". Journal of the History of Economic Thought, 31(2): 216-225.

Marzuki, Peter Mahmud. (2010). Penelitian Hukum, Cetakan ke-6. Jakarta: Kencana Prenada Media Group

McLeod, Ian. (2005). Legal Theory (Palgrave Law Masters). New York: Palgrave MacMillan Ltd. 
Muyassarotussolichah. (2007). “Aliran Teori Hukum Kritis: Analisis Ekonomi terhadap Hukum (The Economic Analysis of Law) Dalam Jurisprudence: Hilaire McCoubrey and Nigel D. White)". SOSIO-RELIGIA, 7(1), 205-229.

Posner, Richard A. (1987). "Wealth Maximization Revisited". Notre Dame Journal of Law, Ethcis, and Public Policy, 2(1), 85-97.

Posner, Richard A. (2014). Economic Analysis of Law. Ninth edition. New York: Wolters Kluwer Law \& Business.

Rahardjo, Satjipto. (2007). Mendudukkan Undang-Undang Dasar, Suatu Pembahasan dari Optik Ilmu Hukum Umum. Semarang: Badan Penerbit Universitas Diponegoro.

Ruslan, Idrus. (2013). "Pemikiran "Kontrak Sosial" Jean Jacques Rousseau Dan Masa Depan Umat Beragama". Undang: Jurnal Hukum, 3(1), 17-36. doi: https://doi.org/10.24042/ajsla.v8i2.583.

Rustamaji, Muhammad. (2013). “Menakar Pengawasan Pemberian Bantuan Hukum Dalam Pandangan Richard A Posner". Jurnal Rechtsvinding: Media Pembangunan Hukum Nasional, 2(1), 95-106. doi: http://dx.doi.org/10.33331/rechtsvinding.v2i1.84

Samekto, FX. Adji. (2019). "Menelusuri Akar Pemikiran Hans Kelsen Tentang Stufenbeautheorie Dalam Pendekatan Normatiffilosofis". Jurnal Hukum Progresif, 7(1), 1-19. doi: https:// doi.org/10.14710/hp.7.1.1-19.

Sari, Nina Amelia Novita et.al. (2019). “Implikasi Penafsiran Hak Menguasai Negara Oleh Mahkamah Konstitusi Terhadap Politik Hukum Agraria Pada PulauPulau Kecil Di Indonesia". Law Review, 19(2), 171-202. doi: http://dx.doi.org/10.19166/lr.v0i2.1874

Shidarta. (2013). Hukum Penalaran dan Penalaran HukumAkar Filosofis. Yogyakarta: Genta Publishing.

Simpson, A. W. B.. (1959). "The Ratio Decidendi of a Case". The Modern Law Review, 22(5), 117-124. doi: https:// doi.org/10.1111/j.1468-2230.1959.tb02164.x

Sudwijayanti. (2017). “Economic Analysis Of Law Terhadap Pemidanaan Insider Trading Dalam Proses Merger Sebagai Kejahatan Korporasi". DiH Jurnal Ilmu Hukum, 13(25), 131-148. doi: https:/ / doi.org/10.30996/dih.v13i25.2227.

Suhardin, Yohanes. (2009). "Fenomena Mengabaikan Keadilan Dalam Penegakan Hukum". Mimbar Hukum, 21(2), 341-354. doi: https://doi.org/10.22146/jmh.16261.

Sulistyorini, Isti dan Siti Zulaekhah. (2017). "Economic Analysis of Law pada Perubahan Kebijakan Kontrak Karya Menjadi Ijin Usaha Pertambangan Khusus (IUPK): Studi Kasus PT. Freeport Indonesia". Pena Justisia: Media Komunikasi dan Kajian Hukum, 17(2): doi: 71-79. doi: http://dx.doi.org/10.31941/pj.v17i2.544.

Urscheler, Lukas Heckendorn dan Seán Patrick Donlan. (2014). Concepts of Law: Comparative, Jurisprudential, and Social Science Perspectives. Farnham: Ashgate Publishing, Ltd.

Wantu, Fence M.. (2013). “Kendala Hakim Dalam Menciptakan Kepastian Hukum, Keadilan, Dan Kemanfaatan Di Peradilan Perdata". Mimbar Hukum, 25(2), 205-218. doi: https:// doi.org/10.22146/jmh.16092. 
1654 - 267-4581 6-165N - 2621-960X

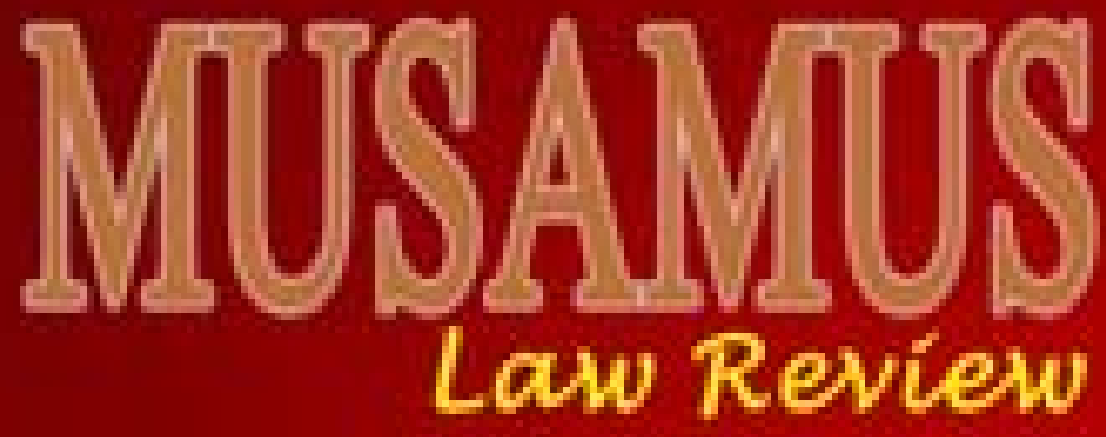

\author{
Hart \\ hit 1 \\ hpllat
}

Publishert

Ficulty of Lnw, Mosmis University Mernike - Indonesia 


\section{Editor in Chief}

Julianto Jover Jotam Kalalo, [ID SCOPUS: 57205235730] Faculty of Law, Musamus University, Indonesia

\section{Managing Editor}

Yuldiana Zesa Azis, [ID SCOPUS: 57207460391$]$, Faculty of Law, Musamus University, Indonesia

\section{Board of Editors}

Flora Pricilia Kalalo, [ID SCOPUS: 57198892232]Faculty of Law, Samratulangi University, Indonesia

Erni Dwita Silambi [ID SCOPUS: 57205339036], Faculty of Law, Musamus University, Indonesia

Ahsan Yunus, [ID SCOPUS:57201773691] Faculty of Law, Hasanuddin University, Indonesia

Rudini Hasyim Rado, [ID SCOPUS: 57212134604]Faculty of Law, Musamus University, Indonesia

Imam Mulvana, Department of International Law, Faculty of Law, Universitas Padjadjaran

Aartje Tehupeiory, Faculty of Law, Indonesian Christian University, Indonesia

Wilma Silalahi, The Constitutional Court of the Republic of Indonesia, Indonesia.

\section{Administrasi}

Nasri Wijava, Faculty of Law, Musamus University, Indonesia 


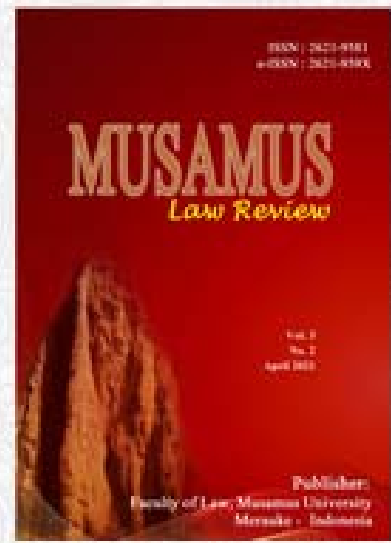

DOt: https://doi.org/10.35724/mularexv3i2

PUBLISHED: 23-04-2021

ARTICLES

Implementation of State Administrative Court Decisions: Conception, and Berriers

Imron Rizki A, Rizki Mustila Suhartono, Safrin Salam

\section{PDF}

Protection of Children in Child Learning During the Covid-19 Pandemic Indonesia

Meydora Cahya Nugrahenti, Hindina Maulida

\section{因 PDF}

Application of Law Enforcement Due Process System in Law Against Child Crimes

Yoslan K. Koni, Marten Bunga, Dince Aisa Kodai, Nurwita Ismail, Mega 5 Tangahu

\section{因 PDF}

Application of Economic Analysis of Law Theory as a Basia for Courts' Judgements in Corruption Crime Cases: (Analyst's Decision of 45/Pid.Sus/TPK/2011/PN.BDG)

\section{T PDF}

The Joint Ministerial Decree (SKB) of lslamic Defenders Front (FPl): Quo Vadis The Rule of Law and Human Rights? 
Journal Profile

\section{Musamus Law Review}

eISSN : 2621959X I pISSN : 26219581

Universitas Musamus

\section{Cînta}

S3

Sinta Score

0

H-Index

0

H5-Index

0

Citations

5 Year Citations 